Abstracta Iranica Abstracta Iranica

Revue bibliographique pour le domaine irano-aryen

Volume 40-41 | 2019

Comptes rendus des publications de 2017-2018

\title{
Stefan Zawadzki. The Rental of Houses in the Neo- Babylonian Period (VI-V Centuries BC)
}

\section{Reinhard Pirngruber}

\section{Q OpenEdition}

12 Journals

\section{Electronic version}

URL: http://journals.openedition.org/abstractairanica/51648

DOI: 10.4000/abstractairanica.51648

ISBN: 1961-960X

ISSN: 1961-960X

Publisher:

CNRS (UMR 7528 Mondes iraniens et indiens), Éditions de l'IFRI

Electronic reference

Reinhard Pirngruber, "Stefan Zawadzki. The Rental of Houses in the Neo-Babylonian Period (VI-V

Centuries BC)", Abstracta Iranica [Online], Volume 40-41 | 2019, document 105, Online since 30

December 2019, connection on 17 April 2021. URL: http://journals.openedition.org/abstractairanica/

51648 ; DOI: https://doi.org/10.4000/abstractairanica.51648

This text was automatically generated on 17 April 2021.

Tous droits réservés 


\title{
Stefan Zawadzki. The Rental of Houses in the Neo-Babylonian Period (VI-V Centuries $B C$ )
}

\author{
Reinhard Pirngruber
}

\section{REFERENCES}

Stefan Zawadzki. The Rental of Houses in the Neo-Babylonian Period (VI-V Centuries BC).

Warschau: Agade Bis, 2018, 343 p.

1 In addition to text editions of 138 cuneiform tablets from Babylonia concerning the topic of house rentals during the Neo-Babylonian and early Achaemenid (539-484 CBE) periods, this monograph also provides a social-historical analysis of aspects the data. The author discusses rental agreements between private persons as well as agreements between temple households (with a particular focus on the Ebabbar temple in Sippar) and individuals, and seeks to quantify the economic importance of the renting out of urban real estate for the temple economy.

2 Overall, the book contains a great amount of very detailed information and its use likely limited to experts of the period only. There are, however, some interesting broader insights, too. According to the author, the precarious political situation at the end of Darius' and early in Xerxes' reigns left a mark in these texts, when precautionary measures such as advance payments and penalty clauses became more frequent (p. 81).

3 More dubious is the claim that the payment of rent in kind - often loaves of bread - is usually connected to difficult personal circumstances; some of these arrangements may rather constitute business relationships where only part of a house was rented out for the purpose of setting up a bakery vel sim.

4 It also seems to be the case that tenants' obligations became more onerous over time, as additional payments (nūptu and šugarrû) were devolved from owner to tenant. By the 
time of Cyrus' conquest of Babylon, such an arrangement has already become standard practice.

\section{AUTHORS}

\section{REINHARD PIRNGRUBER}

Institut für Orientalistik, Wien 